\title{
Rangking Publikasi Ilmiah Internasional Indonesia
}

\section{Oleh Nanang Bagus Subekti}

\section{5}

Publikasi ilmiah dalam jurnal bereputasi internasional berperan sebagai media aktualisasi diri para akademisi dan peneliti dalam pengembangan ilmu pengetahuan secara internasional.

Lebih jauh lagi, jumlah publikasi internasional juga berperan meningkatkan harga diri suatu negara dalam bentuk diplomasi mutu pendidikan dan ilmu pengetahuan. Negara-negara yang memiliki mutu pendidikan dan iptek yang bagus cenderung memiliki jumlah publikasi internasional yang tinggi. Situs olahan pemeringkatan publikasi ilmiah SClmago Lab. (www.scimagojr.com ) melaporkan jumlah publikasi ilmiah dari tahun 1996-2013 berdasarkan data dari SCOPUS.

Portal tersebut memeringkat hasil publikasi 239 negara. Dari portal SCImago diketahui jika Indonesia berada pada urutan ke-61 dengan jumlah publikasi sebanyak 25.481. Indonesia kalah jauh dari negara tetangga ASEAN seperti Malaysia yang menempati urutan ke-37 dengan jumlah publikasi karya ilmiah 125.084, Singapura yang berada di peringkat ke-32 dengan jumlah publikasi 171.037, dan Thailand pada peringkat ke-43 dengan jumlah publikasi 95.690.

Negara ASEAN yang di bawah Indonesia adalah Vietnam dengan peringkat 66 yang memiliki jumlah publikasi sebanyak 20.460. Dari situs SCImago tersebut juga bisa dilihat tiga negara paling produktif menerbitkan karya-karya ilmiah, yaitu untuk peringat ke-1 diduduki oleh Amerika Serikat dengan jumlah publikasi karya ilmiah 7.846.972, peringkat ke-2 adalah Tiongkok (China) dengan jumlah publikasi3.129.719, danperingkatke-3yakni Inggris dengan jumlah publikasi 2.141.375.

Dari rangking publikasi internasional Indonesia di atas, bisa disimpulkan jika jumlah publikasi bereputasi internasional Indonesia cukup memprihatinkan. Hal ini tentu menarik untuk melihat akar permasalahan yang menyebabkan Indonesia memiliki rangking publikasi ilmiah internasional lebih rendah, termasuk dari beberapa negara ASEAN seperti Malaysia, Singapura, dan Thailand. 


\section{Faktor-Faktor Penyebab}

Tidaklah mudah menguraikan akar permasalahan penyebab minimnya publikasi jurnal internasional oleh akademisi di Indonesia. Namun, secara umum bisa dipahami berbagai hal yang menjadikan Indonesia tertinggal dari negara-negara lain. Pertama, penghargaan atas publikasi karya ilmiah. Karya ilmiah belum sepenuhnya menjadi aset yang dipikirkan oleh beberapa perguruan tinggi di Indonesia.

Minimnya penghargaan terhadap peneliti yang mampu lolos publikasi internasional menjadi salah satu penyebabnya. Untuk mengirimkan sebuah artikel ke dalam jurnal internasional tidaklah mudah. Seleksi yang ketat tentu memakan biaya yang tidak murah, baik dalam bentuk materi maupun nonmateri. Semakin tinggi reputasi suatu jurnal, salah satunya adalah impact factor -nya, maka proses seleksi yang dilakukan juga akan semakin ketat. Kedua, keterbatasan sumber daya dan dana.

Untuk menghasilkankaryailmiahyang berkualitas harus didukung oleh penelitian dan sumber referensi yang bermutu. Mahalnya biaya berlangganan jurnal internasional menjadi salah satu penyebab ketertinggalan peneliti Indonesia terhadap perkembangan ilmu pengetahuan. Tidak semua perguruan tinggi di Indonesia memiliki kemampuan finansial yang baik untuk berlangganan jurnal internasional.

Ketiga, lingkungan kerja. Tidak sedikit perguruan tinggi di Indonesia yang belum mampu menyediakan ruang kerja yang representatif bagi dosennya. Ruang kerja untuk dosen sebaiknya dilengkapi dengan fasilitas kerja yang memadai seperti komputer, koneksi internet, rak-rak untuk menampung bukubuku sehingga dosen menjadi nyaman untuk tinggal dan bekerja di kampus.

Selain fasilitas fisik pendukung kinerja dosen, lingkungan kampus yang akademis dengan budaya meneliti dan publikasi yang tinggi akan berpengaruh terhadap gairah menulis dan meneliti para dosen. Keempat, gaji yang belum memadai. Belum semua perguruan tinggi di Indonesia memberikan gaji/penghargaan yang layak untuk dosen-dosennya.

Dampaknya adalah mereka belum bisa sepenuhnya mencurahkan pikiran dan tenaga untuk mengurusi publikasi ilmiah sehingga produktivitas karya ilmiahnya rendah. Kelima, kemampuan bahasa Inggris. Kualitas bahasa Inggris yang baik menjadi faktor penting untuk menentukan apakah sebuahkaryatulislayak untuk diterbitkan atau tidak. Tuntutan kemampuan bahasa Inggris yang berkualitas masih menjadi kendala bagi sebagian besar para akademisi atau peneliti Indonesia. 


\section{Solusi}

Secara objektif perlu juga dipahami jika tidak semua perguruan tinggi (PT) di Indonesia adalah kategori PT-PT yang mapan. PT-PT yang belum mapan kebanyakan masih berjuang supaya bisa survive di tengah-tengah persaingan perguruan tinggi yang semakin ketat dan termasuk semakin ketatnya peraturan penyelenggaraan PT oleh Dikti.

Dampaknya, tidak sedikit PT khususnya PT-PT swasta dan PTPT di daerah yang kecil, akhirnya memberikan prioritas kerjanya supaya bisa tetap bertahan dan tidak gulung tikar. Kondisi seperti ini tentu menjadikan budaya meneliti dan publikasi ilmiah pada jurnal bereputasi internasional akan terabaikan.

Jika dicermati lebih lanjut, negaranegara yang memiliki peringkat karya ilmiah tinggi adalah negaranegara maju yang memiliki PT-PT mapan dan budaya ilmiah yang tinggi. Para akademisi Indonesia yang pernah mengenyam pendidikan atau pernah berkolaborasi penelitian di negara maju pasti sangat memahami perbedaan suasana akademik PT-PT di Indonesia dan negara maju.

Sehingga menjadi sangat menarik untuk dicermati mengapa ketika akademisi Indonesia melakukan studi di negara maju, mereka menjadi sangat produktif. Tapi sebaliknya, setelah kembali ke Tanah Air menjadi kurang produktif. Akhir kata, publikasi bereputasi internasional memiliki persyaratan yang ketat supaya sebuah karya bisa diterima. Misalnya, sebuah penelitian harus memiliki standar kualitas penelitian yang baik dan sajikan dengan bahasa Inggris yang baik pula.

Dua hal ini sebaiknya menjadi prioritas untuk segera dicarikan jalan keluar di samping faktor-faktor yang sudah disebutkan di atas. Perlu juga segera diupayakan supaya PT-PT di Indonesia masuk kategori mapan. Indonesia yang memiliki ratusan ribu dosen yang tersebar di lebih dari 3.000 PT merupakan aset negara yang luar biasa yang harus dijaga, sehingga mampu menjunjung tinggi harkat dan martabat bangsa melalui pengembangan ilmu pengetahuan di mata dunia internasional.

Kolaborasi yang baik antara pemerintah, pengelola perguruan tinggi, dan para dosen atau peneliti menjadi kunci untuk meningkatkan publikasi internasional Indonesia sehingga mampu sejajar dengan negara-negara maju.

\section{Artikel ini pernah diterbitkan di Koran SINDO}

Senin, 13 April 2015 - 12:46 WIB, https://nasional.sindonews.com/read/988644/162/rangking-

publikasi-ilmiah-internasional-indonesia-1428903924 